\title{
Dynamic capabilities strategy for sustainability development in print media management
}

\author{
Febianca Putri ${ }^{1}$, Irwansyah ${ }^{1, *}$, and Monika Pretty Aprilia ${ }^{1}$ \\ ${ }^{1}$ Faculty of Social and Political Sciences, Universitas Indonesia, 10430, Salemba, Indonesia. ${ }^{1}$
}

\begin{abstract}
Nowadays, internet and smart phone turn out to be the new challenge for print media industry. This phenomenon seems to keep on going. It is digitalization that challenges print media companies to develop the sustainable economic growth of company. This research analyses the digital media management applied by Femina Group by using dynamic capabilities. The concept of dynamic capabilities is applied in this research as the main strategy to analyse the survival of print media management in digital era. The dynamic capabilities are divided into three, they are: the capability of sensing, seizing and reconfiguring. The research finds that Femina Group has a strong dynamic capability in sensing and seizing process. Meanwhile, the reconfiguring process of the company suffers a decline in terms of asset protection quality.
\end{abstract}

\section{Introduction}

A boom in digital media development as the result of recent recession has become a call to print media industry [1]. The termination to publish printed edition by several magazines is not only caused by the fall of circulation, but also by inappropriate strategy and business model towards the development in digital era. Digitalization has brought a significant change in communication system, along with its content production, working routine, distribution strategy and business model [2].

Beside management strategy, innovation is also significant to survive. Innovation clearly has become the fundamental key for media industry and for publishers to keep on finding a new solution in print media business, marketing, website, smart phone, advertising and not the least in adjusting and managing their business. Whenever the pressure to improve profit and to maintain position in digital competition increases, innovation is assumed to be the way-out to keep moving forward [1].

Internet and digitalization have made a change in newspaper industry in a rapid speed [4]. In the last few decades, internet, mobile phone, and new reading gadget became the new challenge for magazine publishing industry and this seems keep going forward [1]. Giant media companies also publish their publication online or in any form which is internet accessible [3].

Relatedly, the SDGs also talk about implementation of strategies for sustainable development [5]. Throughout 17 goals, SDG 9 about inclusive and sustainable

\footnotetext{
* Corresponding author: irwansyah09@ui.ac.id
} 
industrialization by focusing on technology, innovation, and sustainable infrastructure become the key pillar of development $[5,6]$. By understanding the challenges, this research also focus on how media in this rapid change of technology develop management by using dynamic capabilities strategy $[1,7]$.

The term 'capability' emphasizes on the main role of strategic management in adjusting, integrating and configuring skills, sources, and competence of internal and external organization effectively to the necessities of the changing environment [7].

In the middle of digital revolution boom in Indonesia, many print media companies, including Femina group, change their business scheme in order to survive in digital era. This research aims to enhance our knowledge about how far print media, especially magazine, can be innovative in confronting new media. This research analyses a case study on digital management strategy of Femina Group.

The goal of this paper is to answer the research questions which are divided into general goal and specific goal. The general goal the research is to understand the dynamic capabilities strategy of media management (namely Femina Group) in producing digital news and information in digital era. The specific goal of the research is to describe the process of sensing, seizing, and reconfiguring of the media management in producing digital news and information.

\section{Literature review}

\subsection{Strategic management}

In the last few decades, Rumelt [8] described in his writings an overview of the strategists on strategic management thought.

Table 1. Overview on strategic management [8].

\begin{tabular}{|c|l|}
\hline Year & \multicolumn{1}{|c|}{ Description } \\
\hline 60 's & Strategy as coordination or integration of the function of market \\
\hline 70 's & $\begin{array}{l}\text { Divided into three strengths; hostility and environmental } \\
\text { uncertainty, development, domination of diversed company }\end{array}$ \\
\hline 80 's & $\begin{array}{l}\text { Porter Strategy [3] on industrial structure through structure- } \\
\text { conduct-performance analysis }\end{array}$ \\
\hline
\end{tabular}

In strategic management, there are some economic thoughts that hesitantly conduct strategic management compared to economy [8], or classic economy [9]. Some groups chose to develop beyond their capability standard, but still maintaining their unique strength and weakness in understanding strategic management. Other groups saw economy as the 'solution' to strategic problems (domination), rejected traditional economy thought with its situational complexity and managerial process. Strategic management is about how a manager or as organization leader makes it to attain the company's goal to survive in market, to keep growing and to seize a competitive advantage, so that the company's goal is suitable with the external environment at that time [9 - 11]. One of the fundamental topics of strategic management study is company performance $[9,12]$.

\subsection{Dynamic capabilities}

Dynamic capabilities can be understood as an approach that emerges and is integrative 
potential to understand the latter source of competitive advantage [7]. Dynamic Capability operates by categorizing it into sensing, seizing, and reconfiguring [13]. Dynamic managerial capability can be divided, in the interest of the analysis, into sensing, seizing and reconfiguring the components containing fundamental cognitive base [13, 14]. Sensing is necessary to notice the chance and threat that emerge from external environment, such as new technology, competitor and readers' need.

Seizing is needed to measure new strategic ideas, for instance, by making a quick and punctual decision on some matters like investation, resource allocation, organizational structure and alliance. Sensing, seizing, and reconfiguring capacities model [7] showed that sensing and seizing is the fundamental prerequisite in reconfiguring resource in terms of rejuvenation and further re-embodiment in organization [15]. Organizational change depends on how the managers sense and interpret the business environment change and how they treat their own chance in making their decisions.

The necessity to sense and seize the chance, and to reconfigure whenever any change happens, demands the allocation, re-allocation, combination, and re-combination of resource and asset. This is the primary strategic function of the executives. Enhancing skill to identify and to treat the complementarity and to manage specialization indeed rarely happened. Finding out how to improve the company's asset value and utility requires a good knowledge on the structure of company's basic asset, and a creativity to provide solution of advanced customer. The creativity may involve new asset establishment, or acquisition and strategic partnership [7].

The general concept of dynamic capabilities [13] towards print media management of media companies is applied in this research. The research analyses the condition that emerges in the media company through three processes, namely sensing, seizing and reconfiguring, that are conducted by the company in terms of producing digital news and information.

\section{Method}

The research applies post-positivism paradigm, to maintained deterministic philosophy by believing that causes (causative factors) are highly possible to determine the final result [17]. Post-positivism paradigm is applied for the research aims to deeply understand the process of dynamic capabilities strategy. Otherwise, the interpretation towards the result of the research can be helpful to give evaluation empirically to media companies today.

The subject of the research is Femina Group. The characteristic of the case is examined through segmentation and existing new media product service [1]. In this research, the researcher conducts both interview and document study towards the subject of the research in order to know the application of dynamic capability strategy based on sensing, seizing, and reconfiguring. The researcher also present the analysis of the answers of the sources related to decision-making logic which is seen through causal and effectual logic. The interview is conducted unstructuredly and openly, it is audio-recorded which latter will be transcripted.

\section{Results and discussion}

Sensing, seizing, reconfiguring, and also identifying threat can be regarded as the measurement to know how strong the company's working in process in dynamic capabilities strategy in producing digital news and information. After interviewing informant $\mathrm{A}, \mathrm{S}$, and $\mathrm{P}$ this are the result of dynamic capabilities. 
Table 2. The result of dynamic capabilities.

\begin{tabular}{|c|l|l|l|}
\hline No & \multicolumn{1}{|c|}{ Sensing } & \multicolumn{1}{c|}{ Seizing } & \multicolumn{1}{c|}{ Reconfiguring } \\
\hline 1 & $\begin{array}{l}\text { Digital content } \\
\text { uniqueness: } \\
\text { feature news }\end{array}$ & $\begin{array}{l}\text { Inter-brand integrated new } \\
\text { business model for } \\
\text { sustainable economic } \\
\text { growth company }\end{array}$ & $\begin{array}{l}\text { Maintaining } \\
\text { company's credibility } \\
\text { by taking the } \\
\text { responsibility } \\
\text { professionally }\end{array}$ \\
\hline 2 & $\begin{array}{l}\text { Focus on } \\
\text { company } \\
\text { sustainable } \\
\text { business model }\end{array}$ & Slow regeneration & Training jam \\
\hline 3 & $\begin{array}{l}\text { Database } \\
\text { Credibility of } \\
\text { Community } \\
\text { Power House }\end{array}$ & $\begin{array}{l}\text { Journalist are loyal } \\
\text { because of a high working } \\
\text { tolerance, as career } \\
\text { women, family business } \\
\text { and education, and also a } \\
\text { solid teamwork. }\end{array}$ & $\begin{array}{l}\text { A shake in industry, } \\
\text { the company shakes as } \\
\text { well and suffers a cash } \\
\text { flow in regard to } \\
\text { business scheme }\end{array}$ \\
\hline
\end{tabular}

The process of sensing of the company in sensing digital news and information to measure dynamic capabilities of the company is found in the moment when they noticed the possibility of internet coming to Indonesia, read the readers' need (including market/media industry), formed a print and online integrated team under one leader, identified online content of Femina Group namely feature news, be aware of the challenge brought by the rapid flow of digital market, identified the uniqueness of digital platform in forming digital character and identified readers' responses in responding feedbacks.

The seizing process of Femina Group in digital news and information, in order to fulfil the dynamic capabilities of the company is conducted through a certain strategy of the company in running the business that involves digital media. In terms of company strategy, Femina Group has a new business scheme that has been implemented since the beginning of 2018. The new business scheme that considers digital media sustainability matter of Femina Group has brought a new value offered to the readers. Meanwhile, the decisionmaking on management, especially in relation with developing navigation (innovation), content editing, and business or marketing ideas is handed over to the CEO, through a closed discussion within the management board. In terms of digital news and information, the company is aware of its limitation in facing the challenge in the rapid flow technological development. However, in terms of measuring the loyalty level of the human resource, the company gives a flexible working environment, such as the female workers of life-style magazine Femina Group are given loose conditions to fulfil their needs to take care of their family, career or to achieve higher education.

The process of general overview or reconfiguring of digital management of Femina Group in digital news and information to gain dynamic capability can be identified through looking how they maintain the company's product credibility in order to enhance competitiveness. An effort to protect company's asset is also conducted, but has not been strong enough, because of a jam in staff trainings, and yet staffs as human resource are one of the company's assets. Skill upgrading like trainings is stopped so the developing human resource's capability is inclined to decline. However, the company's demand on human resource's comprehension towards digital news and information increases.

Interpreting the findings, considering the result of interview process, the research made conclusion as follows: the three informants have dynamic view in sensing digital media management of Femina Group; Informant A keeps talking about the plan to gain an efficient business and optimum profit; Informant $\mathrm{S}$ strives for pushing the company in a 
leading position, strategically enhances the awareness from the business partners and the customers to market that Femina Group has an iconic characteristic in woman life-style, and has an awareness about the sustainability business of the company; Informant P focuses on media content, working teams, and be responsible on the balance between business and editorial affair.

Dynamic capabilities and sustainability researches emerged in some of previous studies. In some studies, it was explained that dynamic capabilities are the right strategy to maintain the sustainability of a company. Mebratu (1998) in reference [18], explains that sustainability must be part of the company's strategy. Companies should prioritize changes in behavior, culture and interests. One of the strategy that Femina Group choose by changing business model. Werbach (2010) as in reference [18] added that sustainability must be at the core of the business and bring innovation. Companies that are unable to innovate will have difficulty in surviving.

$\mathrm{Wu}$ and $\mathrm{Zu} \mathrm{[19],} \mathrm{explained} \mathrm{that} \mathrm{innovation} \mathrm{is} \mathrm{something} \mathrm{that} \mathrm{is} \mathrm{needed} \mathrm{by} \mathrm{the} \mathrm{company.}$ This is due to fast changing environment. Therefore, innovation and sustainability become the main business concerns in the 21 st century. Companies must innovate to respond to environmental that changes fast [19].

Media industry has to experience many changes in order to survive. Dynamic capabilities theory is assessed in many of management studies, as the most appropriate concept as a media effort to survive in an industry that is fast and unpredictable. Reference [20] in a research about media industry in the United Kingdom mentions that dynamic capabilities can not only be an organizational strategy in order to increase adaptive excellence because of competition. However, dynamic capabilities are also a way to prepare the company's foundation for the long-term sustainability [20].

In this study shows that Femina Group already used dynamic capabilities as a way to do sustainability in media industry. With sensing, seizing and reconfiguring, Femina Group conducted many strategies for surviving and competing with survivors. There are three things found in various studies why dynamic capabilities are the most appropriate concept for the media industry to continue to be able to do sustainability [20]; considered as a link between company resources [20], refers to the drive and enthusiasm of mediacompanies to renew resources in order to improve the company's income $[22,23]$, resources that are able to create a competitive advantage that cannot be imitated by their competitors [24].

\section{Conclusions}

This study use a media company named Femina Group as a research subject. Femina is one of Indonesian media who conducts dynamic capabilities strategy in producing digital news and information in digital era has a dynamic capability in regard of sensing and seizing processes. Meanwhile, in carrying out the reconfiguring process of its dynamic capabilities, namely to rejuvenate, adjust, and modify the resources - competence, asset, and capability - by gaining new adaptable resource or by rejuvenating competence by holding trainings, weaknesses are found that prevent the company to develop any further.

Strategic and interactive solutions between client and business partner is maintained by the company to protect their asset. In terms of decision-making logic on credibility, Femina Group emphasizes on effectual decision-making logic. For instance, when there was a stuck between client and editorial board, the company took a concrete solution to form a special team to complete the delayed affairs. Giving responses towards negative issues is completed to protect the business. Human resource training is conducted to boost their capability to be more adaptable with sustainable media development. 


\section{Acknowledgments}

This work is supported by Hibah PITTA 2018 funded by DRPM Universitas Indonesia No.5000/UN2.R3.1/HKP.05.00/2018.

\section{References}

1. A. Johansson, Hanna-Kaisa Ellonen, Ari Jantunen, Magazine Publishers Embracing New Media: Exploring Their Capabilities and Decision Making Logic (2015)

2. C. Andreu Casero-Ripollés, Journal of Media Business Studies 20, 39, 151-158 (2012)

3. S. Biagi, Media/Impact Pengantar Media Massa Edisi 9 (Salemba Humanika, Jakarta, 2010)

4. J. Karimi, Zhiping Walter, The Role of Dynamic Capabilities in Responding to Digital Disruption: A Factor-Based Study of the Newspaper Industry (2015)

5. W. Leal Filho, S.K. Tripathib, J.S.O.D. Andrade Guerra, R. Giné-Garrigad, V. Orlovic Lovrene, J. Willatsf, Using the sustainable development goals towards a better understanding of sustainability challenges (2018)

6. United Nations United nations official website (2016). Available at: https://sustainabledevelopment.un.org

7. D.J. Teece, Gary Pisano, Amy Shuen, Strategic Management Journal 18, 7, 509-533 (1997)

8. R. P. Rumelt, Dan Schendel, David J. Teece, Strategic management and economics 529 (1991)

9. G. David Abreu Pederzini, Strategic management cultures: historical connections with science, 214-235 (2016)

10. J.L. Denis, L. Lamothe, A. Langley, Academy of Management Journal 44, 809-837 (2001)

11. L. Freedman, Strategy: A History 37, 2, 332-334 (2013)

12. M.A. Peteraf, The Cornerstones of Competitive Advantage: a Resource-Based View 179-191 (1993)

13. D.J. Teece, Explicating Dynamic Capabilities: The Nature and Microfoundations of (Sustainable) Enterprise Performance (2007)

14. R. Adner, Constance E. Helfat, Corporate effects and dynamic managerial capabilities, 1011-1025 (2003)

15. E. Danneels, Strategic Management Journal 23, 1095-1121 (2002)

16. E. JE, P.A. Pavlou, Technology-based new product development partnerships (2006)

17. J.W. Creswell, Research Design Pendekatan Kualitatid, Kuantitatif, dan Mixed (SAGE Publication, 1998)

18. L.B. Liboni, C.J.C.A. Jabbour, K. Devika, Journal of Cleaner Production (2016)

19. J. Cabral, The International Conference on Industrial Engineering and Operations Management, At São Carlos - SP 1 (2010)

20. J.J. Oliver. Dynamic Capabilities and Adaptive Advantage in UK Media. In: European Media Management Associaiton, 28-29 May 2015 (Hamburg, Germany, 2015)

21. J.J. Oliver, Strategic Direction 28, 10, 3-5 (2012)

22. K. Eisenhardt, J. Martin, Strategic Management Journal 21, 1105-1121 (2000)

23. V. Ambrosini, C. Bowman, International Journal of Management Reviews 11, 1, 29-49 (2009)

24. M. Zollo, S.G. Winter, Organization Science 13, 339-351 (2002) 